\title{
KAJIAN KANDUNGANTIMBAL DALAM AIR SUMUR GALI DI SEKITAR TEMPAT PEMBUANGAN AKHIR SAMPAH SUKAWINATAN KOTA PALEMBANG
}

\author{
Maksuk, ${ }^{1}$ Suzanna ${ }^{2}$ \\ ${ }^{1}$ Poltekkes Kemenkes Palembang \\ ${ }^{2}$ Balai Teknik Kesehatan Lingkungan Palembang
STUDY OF LEAD CONTAINING IN DUG WELL WATER AT SUKAWINATAN DUMPING SITE IN PALEMBANG CITY

\begin{abstract}
Background: The dumping site is the end place to stock up on various types of waste. One of them is heavy metals such as lead. Lead is one of heavy metal that is very toxic to human mainly children. This study aims to analyse lead containing in dug wells water of community around at the dumping site. Method: This research was a analytical descriptive with cross sectional design. The samples of dug wells water were taken from 5 spots distance from waste dumping location, they were 100 metres, 200 metres, 300 metres, 400 metres and 500 metres, so total samples were 15. The sampling technique was purposive sampling. Lead containing was examined in laboratory by Atomic Absorption Spectrometry (AAS) with SNI 6969.8.2000 method. $\mathrm{pH}$ and temperature measurements were tested in situ, while for physical qualities of dug well water was observed by check list.

Results: The results of observation that the dug wells construction were not qualified construction as many as 93,3\% , but physical qualities of dug well water were qualified. The average of lead containing in dug well water was $0.03 \mathrm{mg} / \mathrm{L}$, with range were between $0.012-0.052 \mathrm{mg} / \mathrm{L}$, while the $\mathrm{pH}$ of dug well water were between 3.2 - 6.7, it was classified as acid. Namun jika dibandingkan dengan persyaratan air minum kadar timbal dalam sumur gali tidak memenuhi syarat.

Conclusion: Lead containing was found in dug well water was safe, but there was one of dug well water that was above environmental quality standards. However, when compared with drinking water requirements, lead levels in dug wells were not qualified. Therefore it is necessary the participation of community and role of local government was needed to treatment the dug well water before using it and improving contruction of dug well.
\end{abstract}

Keywords: Lead containing, dug well water, dumping site

\begin{abstract}
ABSTRAK
Latar Belakang: Tempat pembuangan akhir sampah merupakan tempat akhir untuk menimbun berbagai jenis sampah. salah satu jenis sampah tersebut berupa logam berat diantaranya timbal. Timbal merupakan salah satu logam berat yang sangat beracun bagi manusia terutama anak - anak. Penelitian ini bertujuan untuk mengkaji kandungan logam berat timbal dalam sumur gali masyarakat yang bertempat tinggal di sekitar Tempat Pembuangan Akhir Sampah Kota Palembang.

Metode: Penelitian ini bersifat deskriptif analitik dengan desain cross sectional. Contoh uji diambil dari 5 jarak dengan kriteria jarak 100 meter, 200 meter, 300 meter, 400 meter dan 500 meter dari TPA, jumlah contoh uji sebanyak 15 sumur gali, teknik pengambilan sampel dilakukan teknik purposive sampling. Pengujian kandungan timbal dilakukan di laboratorium menggunakan Atomic Absorption Spectrometry (AAS) dengan metode SNI 6969.8.2000. Pengukuran $\mathrm{pH}$ dan suhu dilakukan secara in situ, sedangkan untuk kondisi konstruksi sumur gali dan kualitas fisik air sumur menggunakan lembar observasi.

Hasil: Hasil pengamatan menunjukkan bahwa kondisi konstruksi sumur gali yang tidak memenuhi syarat konstruksi sebanyak 93,3\%,tetapi kualitas fisik air sumur gali (warna, bau dan rasa)memenuhi syarat kesehatan. Rerata kandungan timbal dalam sumur gali masyarakat yaitu $0,03 \mathrm{mg} / \mathrm{L}$ dengan rentang nilai yaitu $0,012-0,052 \mathrm{mg} / \mathrm{L}$, dari 15 sumur gali ada 1 sumur yang melebihi nilai baku mutu lingkungan, sedangkan pH air sumur gali berkisar antara 3,2-6,7. Namun jika kadar timbal dalam sumur gali dibandingkan dengan persyaratan air minum maka semuanya tidak memenuhi syarat untuk air minum.

Kesimpulan: Kandungan timbal dalam air sumur gali masyarakat yang bertempat tinggal di sekitar Tempat Pembuangan Akhir Sampah Kota Palembang ditemukan masih berada dibawah baku mutu persyaratan air bersih, hanya ada satu sumur yang kandungan timbal melebihi nilai baku mutu. Oleh karena itu partisipasi
\end{abstract}

Alamat Koresponding: Maksuk, PoltekkesKemenkes PalembangEmail: maksuk@poltekkespalembang.ac.id 
masyarakat dan peran pemerintah setempat diperlukan untuk melakukan pengolahan air sumur dan memperbaiki konstruksi sumur gali masyarakat yang berada di sekitar pembuangan akhir sampah.

Kata Kunci: Timbal, sumur gali, tempat pembuangan akhir sampah

PENDAHULUAN

Seiring dengan pertambahan jumlah penduduk, maka semakin meningkat aktivitas yang dilakukan berbagai sektor dalam menghasilkan jenis dan volume sampah.Sampah merupakan sisa kegiatan sehari-hari manusia maupun proses alam yang berbentuk padat. ${ }^{1}$ Akibat meningkatnya jenis dan volume sampah maka dapat menimbulkan berbagai permasalahan terutama masalah kesehatan bagi masyarakat apabila tidak dilakukan pengelolaan dengan baik dan optimal. Pengelolaan sampah di berbagai kota di Indonesia termasuk Kota Palembang masih banyak yang menggunakan sistem open dumping. Pengelolaan sampah di Tempat Pembuangan Akhir Sukawinatan Kota Palembang menggunakan metode open dumping.

Kota Palembang termasuk salah satu kota besar yang mempunyai permasalahan sampah yang juga di alami oleh kota - kota lain di Indonesia. Jumlah penduduk Kota Palembang saat ini sekitar 1.665.681 jiwa, ${ }^{2}$ dengan jumlah penduduk yang mencapai 1,6 juta jiwa tentunya akan menyumbangkan berbagai jenis sampah di Kota Palembang. Setiap harinya volume sampah yang dihasilkan di Kota Palembang kurang lebih 700 ton/hari, dan setiap orang dapat menghasilkan sampah di kota besar termasuk Palembang sekitar $0,5 \mathrm{~kg} /$ orang/hari. ${ }^{3}$ Di Kota Palembang pengelolaan sampah masih bertumpu pada pendekatan akhir (end of pipe), yaitu sampah dikumpulkan, diangkut dan dibuang ke Tempat Pembuangan Akhir (TPA). Salah satu Tempat Pembuangan Akhir (TPA) sampah dalam di Kota Palembang yaitu: TPA Sukawinatan. TPA Sukawinatan beroperasi sejak tahun 1994 dengan luas lahan 25 hektar telah terpakai 15 hektar, dan sisa lahan 10 hektar diperkirakan dapat menampung sampah hingga tahun $2017 .^{3}$
Kadar timbal pada Air lindi di TPA Sukawinatan ditemukan sebesar $1 \mathrm{mg} / \mathrm{L}$ dan kadar Timbal dalam kompartemen air zona dalam TPA rata- rata $0,043 \mathrm{mg} / \mathrm{L}$ dan zona luar TPA rata rata $0,028 \mathrm{mg} / \mathrm{L} .{ }^{4}$ Selain itu kadar timbal pada lindi di TPA Pakusari Jember juga ditemukan sebesar $0,141 \mathrm{ppm}^{5}$ dan di lokasi TPA Air Dingin Padang ditemukan sebesar $0,17 \mathrm{mg} / \mathrm{L}{ }^{6}$ Tingginya kadar timbal diperkirakan berasal dari sampah yang tercampur dalam tumpukan sampah di TPA Sukawinatan seperti bekas baterai, kantong plastik, botol plastik bekas, pembungkus rokok, kaleng bekas dan sisa sisa sampah lainnya hasil kegiatan rumah tangga, industri, perkantoran dan lain - lain. Akibat rembesan air lindi mengikuti aliran air, maka dapat mencemari sumber air tanah masyarakat yang bertempat tinggal di sekitar Tempat Pembuangan Akhir Sampah. Dari beberapa penelitian dilaporkan bahwa ratarata kandungan timbal $(\mathrm{Pb})$ dalam sumur pantau di TPA Pakusari Jember ditemukan sebesar $0,152 \mathrm{ppm}^{5}$ dan dalam air tanah di lokasi TPA Air Dingin Padang sebesar 0,07 $\mathrm{mg} / \mathrm{L}{ }^{6}$

Berdasarkan hasil penelitian yang telah dilakukan sebelumnya bahwa konsentrasi timbal ditemukan pada beberapa sumber air tanah di sekitar Tempat Pembuangan Air sampah. Hal ini dapat menyebabkan air tanah yang digunakan masyarakat di sekitar TPA menjadi tercemar. Dari segi kualitas air yang mengandung timbal melebihi baku mutu tidak layak untuk dikonsumsi, akan tetapi masyarakat di sekitar TPA termasuk masyarakat yang bertempat tinggal di sekitar TPA Sukawinatan masih menggunakan air yang berasal dari air sumur. Oleh karena itu amat penting dilakukan kajian mengenai cemaran logam berat timbal dalam sumur gali yang digunakan masyarakat di sekitar TPA Sukawinatan Kota Palembang. 


\section{METODE}

Penelitian ini merupakan penelitian deskriptif dengan desain cross sectional. Penelitian dilaksanakan pada bulan Oktober 2017 di Tempat Pembuangan Akhir Sukawinatan Kota Palembang. Teknik pengambilan contoh uji air sumur gali dengan cara purposive sampling yaitu dengan pertimbangan jarak sumur dengan TPA. Contoh uji diambil dari 5 titik dengan jarak 100 meter, 200 meter, 300 meter, 400 meter dan 500 meter dari tempat pembuangan akhir sampah, sehingga total jumlah contoh uji sebanyak 15 sumur gali. Selain itu dilakukan observasi untuk kondisi konstruksi sumur gali dan kualitas fisik (rasa, bau, warna) air sumur gali menggunakan lembar observasi.
Pemeriksaan $\mathrm{pH}$ dan suhu air sumur gali dilakukan di lokasi studi (in situ) menggunakan $\mathrm{pH}$ meter dan termometer, untuk pengujian kandungan timbal $(\mathrm{Pb})$ dalam air sumur gali dilakukan di Laboratorium Balai Teknik Kesehatan Lingkungan dan Pengendalian Penyakit (BTKL PP) Palembang menggunakan Atomic Absorbtion Spectrophotometry (AAS) dengan metode SNI 6969.8.2000.

\section{HASIL PENELITIAN}

Berdasarkan hasil observasi kondisi fisik sumur gali masyarakat di sekitar TPA Sukawinatan dijelaskan pada tabel dibawah ini

Tabel 1.

Kondisi Konstruksi Sumur Gali dan Kualitas Fisik Air Sumur Gali Masyarakat di Sekitar TPA Sukawinatan Kota Palembang $(n=15)$

\begin{tabular}{lccc}
\hline \multicolumn{1}{c}{ Variabel } & MS & TMS & \multirow{2}{*}{ Total (\%) } \\
\cline { 2 - 3 } & Jumlah (\%) & Jumlah (\%) & \\
\cline { 1 - 2 } Kondisi Konstruksi Sumur Gali & & & \\
a. Dinding $\geq$ 3 meter dari bahan kedap air (beton) & $1(6,6)$ & $14(93,3)$ & $15(100)$ \\
b. Lantai $\geq 1$ meter dari bahan kedap air & $1(6,6)$ & $14(93,3)$ & $15(100)$ \\
c. Bibir $\geq 0,7$ meter dari bahan kedap air & $1(6,6)$ & $14(93,3)$ & $15(100)$ \\
Kualitas Fisik Air Sumur Gali & & & \\
a. Warna & $15(100)$ & 0 & $15(100)$ \\
b. Bau & $15(100)$ & 0 & $15(100)$ \\
c. Rasa & $15(100)$ & 0 & $15(100)$ \\
\hline
\end{tabular}

Ket: MS : Memenuhi Syarat, TMS : Tidak Memenuhi Syarat

Berdasarkan Tabel 1 bahwa kondisi konstruksi sumur gali yang tidak memenuhi syarat konstruksi sebanyak 93,3\%. Dari hasil pengamatan dijelaskan bahwa konstruksi sumur gali masyarakat di sekitar TPA Sukawinan mempunyai dinding yang tidak kedap air tetapi hanya didinding dengan batu bata dan ada yang tidak berdinding. Sedangkan berdasarkan kualitas fisik (warna, bau dan rasa) air sumur gali ke 15 sumur memenuhi syarat.
Hasil PengujianpH, Suhu dan Kandungan Timbal Air Sumur Gali Berdasarkan Jarak Sumur dengan TPA Sukawinatan Kota Palembang

Selanjutnya hasil pemeriksaan suhu, $\mathrm{pH}$ dan kandungan timbal dalam air sumur gali masyarakat di sekitar TPA Sukawinatan dijelaskan pada tabel dibawah ini : 
Tabel 2.

Kadar Timbal Berdasarkan Jarak Sumur, Suhu Air dan pH Air dengan Tempat Pembuangan Akhir (TPA) Sampah Sukawinatan Kota Palembang

\begin{tabular}{ccccc}
\hline Sumur & $\begin{array}{c}\text { Jarak Sumur dengan TPA } \\
(\mathbf{m e t e r})\end{array}$ & Suhu Air $\left({ }^{\mathbf{0}} \mathbf{C}\right)$ & $\mathbf{p H}$ air & Kadar $\mathbf{P b}(\mathbf{m g} / \mathbf{L})$ \\
\hline 1 & 500 & 28,4 & & 0,023 \\
2 & 500 & 29 & 5,8 & 0,032 \\
3 & 500 & 29 & 5,4 & 0,052 \\
4 & 200 & 29,4 & 6,7 & 0,018 \\
5 & 200 & 28 & 5,7 & 0,033 \\
6 & 200 & 29 & 4 & 0,038 \\
7 & 400 & 28,5 & 4,7 & 0,03 \\
8 & 400 & 28,9 & 5,7 & 0,03 \\
9 & 200 & 29,2 & 4 & 0,044 \\
10 & 200 & 29 & 5,5 & 0,024 \\
11 & 200 & 29,2 & 4 & 0,021 \\
12 & 100 & 27,8 & 5,9 & 0,012 \\
13 & 300 & 28,2 & 3.8 & 0,022 \\
14 & 100 & 29,4 & 4 & 0,017 \\
15 & 100 & 31,6 & 4,21 & 0,043 \\
\hline
\end{tabular}

Berdasarkan Tabel 2 dijelaskan bahwa jarak sumur dengan TPA diambil dari jarak $100-500$ meter. Sedangkan rerata suhu air sumur gali berkisar antara $28^{\circ} \mathrm{C}$ sampai $31,6^{\circ} \mathrm{C}$ dan rerata $\mathrm{pH}$ air sumur gali berkisar antara 3,2-6,7, kondisi air sumur dengan $\mathrm{pH}$ tersebut dikategorikan asam.

Hasil Uji Korelasi Jarak Sumur, Suhu Air, pH dengan Kadar Timbal dalam Air SUmur Gali Di Sekitar TPA Sukawinatan

Tabel 3.

Korelasi Jarak Sumur, Kedalaman Sumur, Suhu Air, dan pH air dengan Kadar Timbal dalam Air Sumur Gali Di Sekitar TPA Sukawinatan $(n=15)$

\begin{tabular}{lcc}
\hline Variabel & r & Nilai p \\
\hline Jarak sumur dengan TPA & 0,294 & 0,288 \\
Kedalaman sumur & 0,112 & 0,691 \\
Suhu air sumur & 0,386 & 0,155 \\
pH air sumur & 0,517 & $\mathbf{0 , 0 4 9}$ \\
\hline
\end{tabular}

Berdasarkan Tabel 3. dijelaskan bahwa dari keempat variabel yaitu jarak sumur dengan TPA, kedalaman sumur, suhu air sumur dan $\mathrm{pH}$ air sumur yang berhubungan secara signifikan dengan kadar timbal dalam sumur gali masyarakat di sekitar TPA Sukawinatan Kota Palembang yaitu $\mathrm{pH}$ air sumur dengan nilai $\mathrm{p}=0,049$ dengan keeratan korelasi kuat. Ini berarti bahwa semakin asam pH air maka kadar timbal dalam air sumur akan semakin tinggi.

\section{PEMBAHASAN}

Kondisi Konstruksi Sumur Gali di Sekitar TPA Sukawainatan Palembang

Berdasarkan hasil pengamatan diperoleh bahwa 93,3\% sumur gali tidak memenuhi syarat konstruksi. Kondisi ini memudahkan penyerapan bahan kontaminan termasuk logam berat timbal yang diabsorpsi tanah dapat memasuki air sumur gali yang digunakan oleh masyarakat di sekitar TPA Sukawinatan.

Sesuai penelitian yang dilakukan pada 10 sumur masyarakat di sekitar tempat penimbunan limbah padat industri timah daur ulang aki bekas di Sei Rotan Kabupaten Deli Serdang yang diobservasi tidak ada satu pun sumur yang memenuhi syarat konstruksi. ${ }^{7}$ Selain itu juga konstruksi sumur yang buruk berpengaruh terhadap kandungan kadmium pada air sumur gali di sekitar TPA Namo Bintang. ${ }^{8}$

Hasil pengamatan mengenai jarak sumur gali dengan tempat penimbunan sampah yaitu 100-500 meter dan masih banyak sumur gali masyarakat di sekitar TPA 
Sukawinatan terletak kurang dari 200 meter dari tempat penimbunan akhir sampah. Kondisi ini menyebabkan air sumur rentan terhadap pencemaran dari tempat penimbunan tersebut. Sesuai penelitian yang dilakukan di sekitar tempat penimbunan limbah padat industri timah daur ulang aki bekas di Sei Rotan Kabupaten Deli Serdang dilaporkan bahwa jarak penimbunan limbah padat dari daur ulang aki kurang dari 200 meter dari sumber air masyarakat juga mendukung terjadi pencemaran timbal. ${ }^{7}$ Jarak sumur di lokasi studi masih ada yang tidak sesuai persyaratan dari Depkes RI (1996) bahwa jarak sumber air bersih (mata air, sumur, sungai, danau dan lain-lain) dengan tempat penimbunan limbah padat di atas 200 meter. $^{9}$

\section{Kualitas Fisik Air Sumur Gali di sekitar TPA Sukawinatan}

Berdasarkan hasil penelitian di lokasi studi diperoleh bahwa kualitas fisik air sumur gali (bau, rasa dan warna) semuanya memenuhi syarat. Sesuai Permenkes No.32 Tahun 2017 tentang persyaratan air bersih dan Permenkes RI Permenkes No. 492/Menkes/per/IV/2010 tentang persyaratan air minum bahwa secara fisik air tidak boleh berwarna, berbau dan berasa. Meskipun demikian parameter fisik lainnya sesuai Permenkes tersebut tidak boleh diabaikan.

Air yang digunakan untuk keperluan sehari-hari harus jernih (tidak berwarna, tidak berasa, dan berbau). ${ }^{10}$ Hal ini tidak sesuai dengan studi pada air tanah masyarakat di Kelurahan Sumur Batu Kecamatan Bandar Gebang dilaporkan bahwa kualitas fisik air yaitu yang berasa sebanyak $30,6 \%$, berbau sebanyak $25 \%$ dan berwarna sebanyak $18,1 \%$. 11

\section{Hasil Pengujian pH, Suhu dan Kandungan Timbal Air Sumur Gali Berdasarkan Jarak Sumur dengan TPA Sukawinatan Kota Palembang}

Rerata suhu air sumur gali relatif normal, tetapi $\mathrm{pH}$ air sumur gali cenderung asam, sedangkan kadar timbal dalam air sumur gali jika dibandingkan dengan Permenkes No. 32 Tahun $2017<0,05$ mg/L (masih dibawah nilai baku mutu). ${ }^{12}$ Namun jika dibandingkan dengan Permenkes No. 492/Menkes/per/IV/2010 tentang persyaratan air minum kadar timbal dalam air sumur gali semuanya $>0,01 \mathrm{mg} / \mathrm{L}$ (melebihi nilai maksimum yang diperkenankan). ${ }^{13}$ Meskipun dari 14 sumur yang dilakukan pengujian kadar timbal diperoleh nilai kurang dari baku mutu, hal ini tidak dapat dikatakan aman karena dalam jangka waktu yang lama kadar timbal tersebut dapat meningkat. Oleh karena itu air sumur gali di lokasi studi tidak layak untuk digunakan sebagai sumber air minum.

Perbedaan kadar timbal dalam air sumur gali juga ditentukan oleh jarak sumur dengan TPA. Hal ini sesuai dengan penelitian yang dilakukan di tempat penimbunan sampah aki bekas Deli Serdang dimana jarak sumur yang diperiksa berkisar antara 25- 200 meter. $^{7}$ Hasil penelitian ini tidak sejalan dengan hasil pengujian sampel air sumur monitoring di TPA Pakusari dilaporkan bahwa kandungan logam berat timbal melebihi baku mutu lingkungan. ${ }^{5}$ Sumur monitoring merupakan sumur yang digunakan untuk memantau muka dan mutu air bawah tanah dan air permukaan pada ekuifer tertentu. ${ }^{14}$

Sesuai hasil penelitian pada air tanah dangkal di TPA Air Dingin Padang dilaporkan bahwa suhu air tanah sumur dangkal berkisar 24,9-25,7 ${ }^{\circ} \mathrm{C}, \mathrm{pH}$ berkisar 5,94-6,35 dan kadar $\mathrm{Pb}$ dalam air tanah dangkal $0-0,07 \mathrm{mg} / \mathrm{l}^{6}$ Selain itu pemeriksaan laboratorium terhadap kadar Timbal $(\mathrm{Pb})$ pada air sumur gali masyarakat di Desa Sei Rotan diperoleh bahwa kadar timbal $(\mathrm{Pb})$ yang diperiksa melebihi nilai baku mutu. ${ }^{7}$ Sedangkan pada hasil pemeriksaan laboratorium terhadap kandungan timbal pada air sumur gali penduduk di Dusun III Desa Bandar Khalipah terdapat 1 sampel sumur yang tidak memenuhi syarat yaitu dengan kadar $\mathrm{Pb}(0,10$ $\mathrm{mg} / \mathrm{L}){ }^{15}$ Kondisi ini disebabkan konstruksi fisik sumur gali yang di observasi tidak ada 
satu pun yang memenuhi syarat konstruksi sehingga sumur lebih rentan untuk terkontaminasi dengan polutan yang berasal dari tempat pembuangan akhir sampah. ${ }^{14}$

Studi di TPA Namo Bintang menunjukkan bahwa konsentrasi rerata timbal dalam air sumur gali di Dusun I $(0,00498$ $\mathrm{mg} / \mathrm{L}$ ) lebih rendah daripada di Dusun IV $(0,007 \mathrm{mg} / \mathrm{L}){ }^{16}{ }^{16}$ Selain itu hasil analisis kandungan Logam Berat Timbal $(\mathrm{Pb})$ di sekitar Tempat Pembuangan Akhir (TPA) Sampah Desa Marelan Pulau ditemukan sebesar $0,024 \mathrm{mg} / \mathrm{L}$ dengan $\mathrm{pH}$ air $7,4 .^{17}$ Sedangkan di TPA air dingin Kota Padang kadar timbal dalam air sumur $>0,01 \mathrm{mg} / \mathrm{L}$ dengan $\mathrm{pH} 5,3-5,6 .{ }^{18}$ Namun kandungan $\mathrm{Pb}$ pada semua air sumur sampel di wilayah kerja Puskesmas Denpasar Selatan tidak terdeteksi dengan $\mathrm{pH} 6-7 .^{19}$ Selain itu Konsentrasi logam timbal $(\mathrm{Pb})$ ditemukan dalam kolam lindi adalah $0,17 \mathrm{mg} / \mathrm{L}$, kandungan logam timbal $(\mathrm{Pb})$ pada sumur penduduk yaitu 0,02 $\mathrm{mg} / \mathrm{L}$ dan pada sumur pantau $0,17 \mathrm{mg} / \mathrm{L},{ }^{20}$ sedangkan studi yang dilakukan pada sumur di industri pengecoran logam ceper Klaten kadar timbal ditemukan $<0,01 \mathrm{mg} / \mathrm{L} .{ }^{21} \mathrm{Hal}$ ini tidak sesuai dengan studi yang dilakukan pada air sumur artesis di sekitar pabrik karet Pekan Baru dimana kadar timbal dalam air sumur ditemukan antara 0,0043-0,0094 ppm, hasil tersebut masih dibawah baku mutu. ${ }^{22}$

Berdasarkan hasil uji korelasi bahwa hanya $\mathrm{pH}$ air sumur yang berhubungan secara signifikan dengan kadar timbal dalam air sumur gali masyarakat di sekitar Tempat Pembuangan Akhir (TPA) sampah Sukawinatan Kota Palembang. pH asam dapat meningkatkan kelarutan logam berat dalam air tanah. ${ }^{20}$ Hal berbeda dilaporkan pada studi di Eks TPA di Karya Jaya Palembang dimana pH air tanah masih dibawah mutu, hal ini disebabkan saat pengambilan contoh uji dilakukan pada musim kemarau. ${ }^{23}$

Hal ini sesuai dengan studi yang dilakukan pada air sumur masyarakat di sekitar TPA Namo Bintang dimana jarak sumur gali dengan TPA tidak berkorelasi secara bermakna dengan konsentrasi krom, timbal, dan merkuri dalam sumur gali tersebut, jarak dibagi menjadi dua yaitu sumur-sumur gali yang berada dalam radius $<500$ meter dari batas terluar TPA dan $>500$ - 1.000 meter. ${ }^{24}$ Namun, hal ini tidak sesuai dengan hasil temuan yang dilaporkan oleh Oyeku dan Eludoyin bahwa kandungan tembaga, besi, timbal dan kobalt telah melebihi batas yang ditetapkan WHO pada radius 2.000 meter dari TPA Olusosun di Ojota Nigeria. ${ }^{25}$

\section{KESIMPULAN DAN SARAN}

Penelitian ini memberikan informasi penting mengenai kadar timbal dalam air sumur gali masyarakat yang bertempat tinggal di sekitar TPA Sukawinatan Kota Palembang dan semua kondisi konstruksi sumur gali tidak memenuhi syarat. Rerata kadar dalam air sumur gali masyarakat di sekitar TPA Sukawinatan masih berada dibawah baku mutu untuk persyaratan air bersih, hanya ada satu sumur yang kadar timbalnya berada melebihi nilai baku mutu lingkungan. Namun jika dibandingkan baku mutu untuk persyaratan air minum maka air sumur gali di lokasi studi tidak boleh untuk di konsumsi masyarakat di sekitar TPA Sukawinatan kota Palembang.

Oleh karena itu kepada masyarakat yang bertempat tinggal lokasi studi agar dapat memperbaiki konstruksi sumur gali untuk mencegah masuknya bahan kontaminan lainnya. Bagi puskesmas dan Balai Teknik Kesehatan Lingkungan agar dapat bekerja sama melakukan monitoring kadar timbal serta parameter logam berat lainnya dalam air sumur gali secara berkala.

\section{UCAPAN TERIMA KASIH}

Penulis menyampaikan terima kasih kepada Poltekkes Kemenkes Palembang yang telah memberikan bantuan dana sehingga penelitian ini dapat selesai tepat pada waktunya. 


\section{DAFTAR PUSTAKA}

1. Undang-Undang Republik Indonesia Nomor 18 Tahun 2008 Tentang Pengelolaan Sampah

2. BPS Kota Palembang. Statistik Kependudukan Kota Palembang. 2016. https://palembangkota.bps.go.id/linkTable Dinamis/view/id/24.

3. Dinas Kebersihan dan Keindahan. UPTD TPA Sukawintan Kota Palembang. 2016

4. Warsinah, Suheryanto, Windusari Y. Kajian Cemaran Logam Berat Timbal $(\mathrm{Pb})$ pada Kompartemen di Sekitar Tempat Pembuangan Akhir (TPA) Sukawinatan Palembang, Jurnal Penelitian Sains, 2015 ;17 (2): 78-81.

5. Widyasari N, Moelyaningrum AD, Pujiati RS, 2013. Analisis Potensi Pencemaran Timbal $(\mathrm{Pb})$ Pada Tanah, Air Lindi Dan Air Tanah (Sumur Monitoring) di TPA Pakusari Kabupaten Jember Kesehatan Lingkungan dan Kesehatan Keselamatan Kerja Fakultas Kesehatan Masyarakat, Universitas Jember (UNEJ).

6. Komala PS, Primasari B, Rivai F. Pengaruh Sistem Open Dumping Di Lokasi Pembuangan Akhir (LPA) Terhadap Kandungan Logam Berat Pada Air Tanah Dangkal di Sekitarnya (Studi Kasus LPA Air Dingin, Padang), Jurnal TeknikA.2008; 29 (1):1-8.

7. Tumanggor WRE, Dharma S, Marsaulina I. Analisis Kandungan $\mathrm{Pb}$ Pada Air Sumur Gali Masyarakat di Sekitar Tempat Penimbunan Limbah Padat Industri Timah Dari Daur Ulang Aki Bekas Desa Sei Rotan Kecamatan Sei Tuan Kabupaten Deli Serdang Tahun 2012. Program Sarjana Fakultas Kesehatan Masyarakat Universitas Sumatera Utara Departemen Kesehatan Lingkungan.2012.

8. Ompusunggu, H. Skripsi Analisa Kandungan Nitrat Air sumur Gali Masyarakat di Sekitar TPA Sampah di desa Namo Bintang Kecamatan Pancur Batu Kabupaten Deli Serdang. Universitas Sumatera Utara. 2009.

9. Departemen Kesehatan RI. Direktorat Jenderal Pencegahan Penyakit menular dan Penyehatan Lingkungan Pemukiman tentang Air Bersih. Jakarta. 1996.
10.Soemirat J. Kesehatan Lingkungan. Yogyakarta : Gadjah Mada University Press. 2009.

11.Fajarini S. Analisis Kualitas Air Tanah Masyarakat di Sekitar Tempat Pembuangan Akhir (TPA) Sampah Kelurahan Sumur Batu Bandar Gebang Bekasi 2013. Skripsi Universitas Islam Negeri Jakarja Fakultas Kedokteran dan Ilmu Kesehatan. 2013.

12.Permenkes RI No 32 Tahun 2017 tentang Standar Baku Mutu Kesehatan Lingkungan dan Persyaratan Kesehatan Air untuk Keperluan Higiene Sanitasi, Kolam Renang, Solus Per Aqua dan Pemandian Umum.

13.Permenkes 492/Per/IV/2010 tentang Persyaratan Air Minum

14.Irfandi A, Ashar T, Chahaya I, Analisis Kandungan Kadmium (Cd) dan Timbal $(\mathrm{Pb})$ pada Air Sumur Gali Penduduk Di Sekitar Industri Daur Ulang Aki dan Gangguan Kesehatan Pada Masyarakat Desa Bandar Khalipah Kabupaten Deli Serdang Tahun 2013. 2013.https://media.neliti.com/.../14501-IDanalisis-kandungan-kadmium-cd-dantimbal-pb- diakses 18 Desember 2017.

15.Palar, H. 1994. Pencemaran dan Toksikologi Logam Berat. Penerbit Rineka Cipta. Jakarta.

16.Ashar T, Santi DN, Naria E. Kromium, Timbal dan Merkuri dalam Air Sumur Masyarakat di Sekitar Tempat Pembuangan Akhir Sampah. Kesmas, Jurnal Kesehatan Masyarakat Nasional, 2013; 7 (9) : 408-414.

17.Hasibuan P. Analisis Kandungan Logam Berat Timbal $(\mathrm{Pb})$, Besi $(\mathrm{Fe})$ dan $\mathrm{pH}$ Pada Air Sumur Gali Di Sekitar Tempat Pembuangan Akhir (TPA) Sampah Desa Marelan Pulau Nibung Kota Medan. Skripsi Fakultas Matematika dan Ilmu Pengetahuan Alam Universitas Negeri Medan. 2016.

18.Wardi E S, Arel A, Yongki B.Analisa Kandungan Timbal $(\mathrm{Pb})$ dan Kromium (Cr) Air Sumur di TPA Air Dingin Kota Padang, Scientia, 2018.; 8 (1) : 125 - 129.

19. Marwati NM, Mardani N K, Sundra I K. Kualitas Air Sumur Gali Ditinjau dari Kondisi Lingkungan Fisik dan Perilaku Masyarakat di Wilayah Puskesmas I 
Denpasar Selatan, Ecotrophic. 2008; 5 (1) : $63-69$.

20.Fatmawinir, Suyani H, Alif A, Analisis Sebaran Logam Berat Pada Aliran Air dari Tempat Pembuangan Akhir (TPA) Sampah Air Dingin, Jurnal Riset Kimia. 2015; Vol. 8 (2) : 101-107.

21.Mulya Sari G, Munawar, Napoleon A. Kualitas Air Tanah di Sekitar Eks Tempat Pembuangan Akhir Karya Jaya Palembang, Bioscientiae. 2015; Vol. 12 (1): 90-101.

22.Usman PS. Analisis Kadar Logam Kromium dan Timbal pada Air Sumur Artesis Daerah Sekitar Pabrik Pengolahan Karet PT. Bangkinang Pekan Baru dengan Menggunakan Spektrofotometri Serapan
Atom (SSA). Skripsi UIN Sultan Syaraif Kasim Riau Pekanbaru. 2014.

23.Susanto JP. Analisis Deskripsi Pencemaran Air Sumur pada Daerah Industri Pengecoran Logam, Jurnal Teknik Lingkungan P3TL - BPPT. 2005; Vol. 6 (2) : 402-409.

24.Ashar T, Santi DN, Naria E. Kromium, Timbal, dan Merkuri dalam Air Sumur Masyarakat di Sekitar Tempat Pembuangan Akhir Sampah, Jurnal Kesehatan Masyarakat Nasional. 2013; 2013; Vol. 7 (9) : 408-414.

25.World Health Organization. Environmental health criteria 61: chromium. Geneva: International Programme on Chemical Safety (IPCS); 1988. 